\title{
Analysis of The Propulsion System Towards The Speed Reduction of Vessels Type PC-43
}

\author{
Arica Dwi Susanto ${ }^{1}$, Ahmadi $^{2}$, Okol S Suharyo ${ }^{3}$, Indrajaya Gerianto ${ }^{4}$ \\ ${ }^{1}$ Indonesian Naval Technology College, Bumimoro-Morokrembangan, Surabaya 60187, Indonesia
}

\begin{abstract}
(PC-43) is an Indonesian navy vessel type limited patrol craft made in Indonesian. The vessel was designed using a steel material with a maximum speed of 27 knots and using engine power by $3 \times 1800 \mathrm{HP}, \mathrm{T}=1.40$ at the empty draft and $\mathrm{T}=1.70$ at full draft. The speed is decreased in the current conditions by 22 knots at 1.50 meters draft within 1 year after its launching. This fact is very interesting to be used as a paper project by analyzing the effect of changes in vessel's draft to the resistance and analyze the current installed engine power, This paper carried two methods of calculation, namely: resistance and power calculation numerically along with resistance and power calculation using software maxsurf. The results from the manual calculations of power at $\mathrm{T}$ $=1.65$ meters in $27 \mathrm{knots}$, the power needed is BHPscr $=4245.04 \mathrm{HP}$. From the data of power installed in the vessel, it was stated that the power is $3 \times 1800=5400 \mathrm{HP}$, means a mathematical/theoretical speed of $27 \mathrm{knots}$ can be achieved. Thus, the resistance and power is not one of the causes of speed reduction in Vessel Type PC43.
\end{abstract}

Keywords : Ship Resistance, Power Boats, Patrol Craft, Sea Trial

\section{INTRODUCTION}

This type of Indonesian Navy Vessel is a Patrol Craft (PC-43) and it was domestically made by Indonesian people in the shipyard of PT. PALINDO MARINE SHIPYARD, Batam. This type of Patrol Craft was designed to carry out tasks according to its basic function as "LIMITED PATROL CRAFT". The vessel was designed using a steel material with a maximum speed of 27 knots. The sailing vessel has the same basic resistance components as a displacement or semi-displacement craft, together with extra components. The fundamental extra component incurred by a sailing vessel is the induced drag resulting from the lift produced by the keel(s) and rudder(s) when moving at a yaw angle (Anthony $\mathrm{F}$. Molland, 2011).

This paper have any literature to support the research about it, for example paper with title Introduction to Naval Architecture (Tupper E. , 1975). Basic Ship Theory (Tupper K. R., 2001). Practical Ship Design (Watson, 1998). Ship Resistance and Propulsion : Practical Estimation of Ship Propulsive Power (Anthony F. Molland, 2011). Practical Ship Hydrodynamics (Bertram V., 2000). Ship Design and Contruction (D'arcalengelo, 1969). Resistance Propulsion and Steering of Ship (WPA Van Lamerren, 1948). Resistance and Propulsion of Ships (Harvald, 1992). Hydrodynamic of Ship Propellers (Andersen, 1994). Ship Design for Efficiency and Economy (Bertram H. S., 1998). Design of Propulsion Systems for High-Speed Craft (Bartee, 1975). Amethod of Calculation of Ship Resistance on Calm Water Useful at Preliminary Stages of Ship Design (Zelazny, 2014).
An Inventigation Into The Resistance Components of Converting a Traditional Monohull Fishing Vessel Into Catamaran Form (Samuel, 2015). Empirical Prediction of Resistance of Fishing Vessels (Kleppesto, 2015). Designing Constraints in Evaluation of Ship Propulsion Power (Charchalis, 2013). Coefficients of Propeller-hull Interaction in Propulsion System of Inland Waterway Vessels with Stern Tunnels (Tabaczek, 2014). Numerical Investigation of the Influence of Water Depth on Ship Resistance (Premchand, 2015). The Wageningen Propeller Series (Kuiper, 1992). Principles of Naval Architecture Second Revision (Lewis, 1988). Marine Propulsion (J. Sladky, 1976).

This paper presents about the speed reached 27 knots at 1.50 meters draft, the speed is decreased in the current conditions by 22 knots at 1.50 meters draft within 1 year after its launching. This could occur because of the draft differences between the sea trial and the operation, or a mismatch between the power efficiency of the machine and the design of the hull. The objective of this study is to analyze the cause of speed reduction based on the vessel's resistance related to the change of vessel's draft and power engine. The benefit of this study is to develop the knowledge and technology of Indonesian Navy ALUTSISTA.

This Paper is organized as follows. Section 2 review about the basic ship theory. Section 3 gives result and discussion of research. Finally, in section 4 present conclusion this paper. 


\section{RESEARCH METHODOLOGY}

\subsection{Technical Concept}

In the design of patrol craft that will be used as limited patrol craft, it is expected to have these conditions:

1. High Accuracy, It allows the tactical and technical information to deliver quickly so that decisions can be obtained accurately and rapidly.

2. High Acquacition, This ensures control over the threat better, it requires the sewaco system and platform to be reliable.

3. High Speed, With the speed and agility of the vessel, it allows to conduct amore dynamic and proper limited patrol.

\section{2}

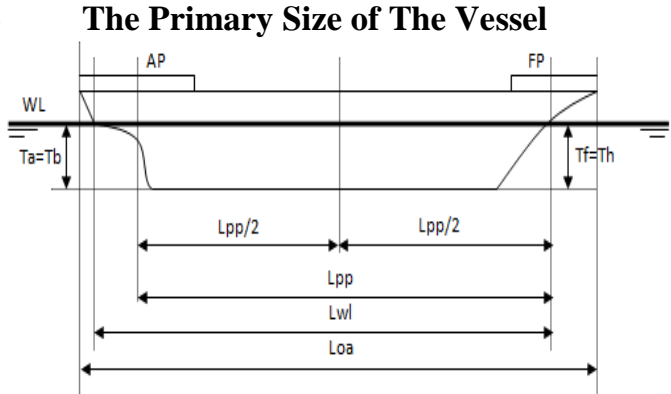

Fig.1: Longitudinal Shape of The Vessel

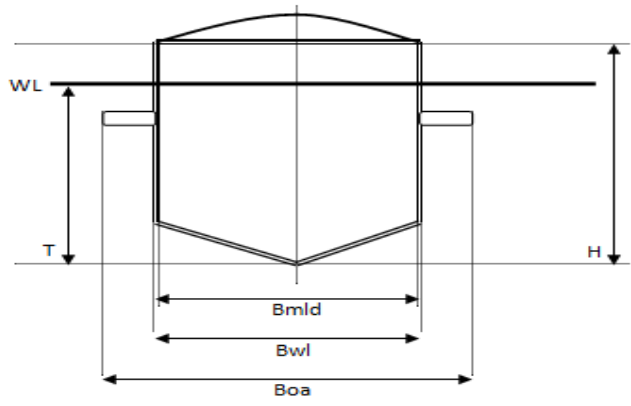

Fig.2: Cross-sectional Shape of The Vessel

1. Vessel Length is one of the primary size of the vessel seen from the longitudinal section as shown in Fig.1: Longitudinal Shape of Vessel, with the following explanation: (Tupper K. R., 2001)

AP (After Perpendicular) is a vertical line that is made through the back of the steering.

FP (Fore Perpendicular) is a vertical line that is made through the intersection between stem and full load of waterline.

Lpp (Length between perpendicular) is the length between vertical line of the stern and vertical bow that is measured on full load of waterline.

Lwl (Length on the water line) is the length from the forwardmost point of the water line measured in profile to the stern-most point of the water line.

Loa (Length Overall) is the extreme length from the start of bow to the end of the stern.

2. Vessel Breadth (B) is one of the primary size of the vessel seen from the cross-sectional as shown in Fig.2: Cross-sectional Shape of The Vessel, with the following explanation: (Tupper K. R., 2001)

Bmld (Breadth moulded) is the horizontal breadth of the amidships measured in the outside of the framework (excluded the thick shell of the hull).

Bwl (Breadth at water line) is the maximum beam or breadth in the waterline of the ship measured in the waterline.

Boa (Breadth over all) is the maximum breadth of the vessel measured from the left side of hull shell to the right side of hull shell, when there is any protrude part of the deck, then the B maximum is that protrude part.

3. The Depth of The Deck $(\mathrm{H})$ is the vertical length from the base line to the lowest deck line measured in the center of the Lpp (Tupper K. R., 2001). Fig.1 : The Longitudinal Shape of The Vessel

4. Draught (T) is a vertical line from the base line to the waterline (Tupper K. R., 2001). Fig.2: Crosssectional Shape of The Vessel

(Tmax) Maximum Draught is a maximum depth of the sunken hull measured from the waterline to the lowest part of the ship. When the keel is even, the draught is applied to all of vessel's part. However, when the keel is not even, there are types of draught namely :

$\mathrm{Th}=\mathrm{Tf}=$ Draught in the bow that is measured in FP (vertical line of bow) $\mathrm{Ta}=\mathrm{Tb}=$ Draught in the stern that is measured in the AP (vertical line of stern)

\subsection{The Hull of The Vessel.}

Regarding the correlation with the propulsion system of vessel, the fact that the body of the vessel in the water and air will get resistance force in the form of hydrodynamic and aerodynamic forces is become the main focus in this discussion.

Vessel resistance at some rate is the fluid force which works opposite to the movement of the vessel. That resistance will be equal with fluid force component which work in parallel with the shaft of vessel's motion (Bertram V., 2000).

Seeing that the ship is engaged in the liquid fluid whose density value is greater than air, it is shown that the increase of the speed and the dimensions of a ship will make the removing energy to produce wave energy increase. This wave will create a friction with the hull with the opposite direction of the vessel and cause opposite force.

Total resistance (RT) on a vessel consists of the componentsor parts of the vessel which has the possibility of causing resistance (Holtrop, 1982). Principally, there are two parts of the ship which experienced the resistance, there are sinking part of the vessel and area above the water surface because the air also has inhibitory factor in certain condition. 
(RT) is used to determine the Efective Horse Power (EHP), which is defined as the power required to actuate a vessel at the speed of (VS) and able to overcome the resistance of (RT) and more importantly, (EHP) is used to know the amount of main power engine in order to avoid the surplus power and the unfulfilled power due to the power which can't overcome the vessel resistance.

Total resistance (RT) of the vessel consists of different components of resistance caused by an interactive variety of causes. Review of the total resistance is practically needed to deal with this resistance in practice also it can be explained into several main components as follows:

1. Resistance Friction occurs due to the friction between wet surface of the vessel and media path. Friction occurs because all of the fluid has a viscosity value. The resistance components are obtained by integrating the tangential tension throughout the wet surface of the vessel in the direction of motion of the vessel. The components of this resistance is shown below (Harvald, 1992):

$\mathrm{Rf}=0,5 . \mathrm{Cf} \cdot \rho \cdot \mathrm{V}^{2} \cdot \mathrm{S}(\mathrm{kN})$

$\mathrm{Rn}=\mathrm{Vs} . \mathrm{Lwl} / \mathrm{v}$

$\mathrm{Cf}=0,075 /(\log 10 \mathrm{Rn}-2)^{2}$

2. Residual Resistance (RR) is the quantity as the result of total resistance reduction of the hull, also known as frictional resistance as the result of the calculation obtained by using a special formula. In general, the maximum part of remain resistance of the vessel is wave making resistance. The formula is shown below (Harvald, 1992) :

$\mathrm{RR}=\left(0,5 \times \rho \times \Delta^{2} / 3 \times \mathrm{V}^{2}\right)$

Remain resistance has coefficient value which is obtained from ratio figures of length and volume which are the correlation between Froude number and elongated prismatic coefficient.

$\mathrm{Fn}=\mathrm{V} / \sqrt{ } \boldsymbol{g} . \boldsymbol{L}$

3. Viscous Resistance is component of the resistance related to energy released caused by viscous (Tupper K. R., 2001).

4. Pressure Resistance (PR) is component of resistance which is obtained by integrated the normal tension to all of the vessel's surface according to the direction of the vessel's motion (Tupper K. R., 2001).
5. Viscous Pressure Resistance (RPV) is component of the resistance which is obtained by integrated normal tension caused by viscous and turbulence. This quantity can't be calculated directly except for completely sinking object, in this case is equal to pressure resistance (Tupper K. R., 2001).

6. Wave making Resistance (RW) is component of resistance which is related to energy released to create gravitation wave (Wehausen, 1971).

7. Wave Pattern Resistance (RWP) is component of resistance which is concluded from the calculation of wave elevation far from vessel model, in this case is the subsurface velocity field. It means the fluid momentum can be assumed to relate to wave pattern using linear theory. The resistance is not included to the wave breaking resistance (Wehausen, 1971).

8. Wave Breaking Resistance (WBR) is component of resistance which is related to wave breaking in the vessel's stern (Wehausen, 1971).

9. Spray Resistance is component of the resistance which is related to energy released to create spray (Harvald, 1992).

10. Appendage Resistance is resistance from the shaft boss, shaft bracket and shaft, bilge keel etc. In using physical models, these models are generally equipped with parts and included in the measurement of resistance. Bilge keel is generally not installed. When the parts is not included, the resistance is called bare resistance (Harvald, 1992).

11. Roughness Resistance is resistance caused by the roughness of the hull surface from corrosion and fouling in the hull (Harvald, 1992).

12. Air Resistance is resistance in the water surface and the superstructure caused by vessel's motion in the air flow (Harvald, 1992).

13. Steering Resistance is resistance caused by the steering. The motion of the steering is directed to the straightening of the path or vessel maneuver (Harvald, 1992).

\subsection{Displacement}

Displacement is the weight of liquid displaced by the hull under the water surface. When the vessel floats in the balance state/motionless then the downward pressure equal to the pressure of the liquid to the hull. Thus the overall weight of the vessel and its contents at that time equal to the weight of liquid displaced by the hull immersed in a liquid in 
which the vessel is located (Anthony F. Molland, 2011).

Displacement : Lwl x B x T x CB x density of sea water (ton)

\subsection{Volume Displacement}

The volume of liquid displaced by the hull under the surfacewater where the ship is located (Anthony F. Molland, 2011).

Volume displacement: LWL x B x T x CB

\subsection{Selection of The Main Engine}

In the selection of the main engine, it is necessary to calculate the need of power engine. There are several indicators that need to be sought in order to obtain the desired results, those are effective horse power (EHP), thrust horse power (THP), delivery horse power (DHP), shaft horse power (SHP) dan brake horse power (BHP) (Anthony F. Molland, 2011).

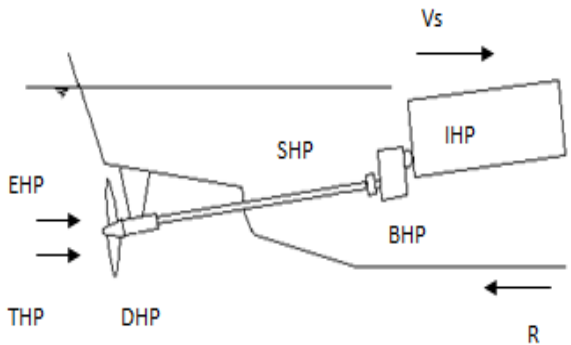

Fig.3: Propulsion System of The Vessel

1. Effective Horse Power (EHP) Is power needed to actuate the vessel in water (without) the presence of wave or to pull the vessel with this equation below (Harvald, 1992) :

$\mathrm{EHP}=\mathrm{RT} \times \mathrm{Vs}$

2. Thrust Horse Power (THP) Is power distributed by the vessel's propeller without influence of the weather or environment condition (Lewis, 1988).

$T H P=\frac{E H P}{\eta \mathrm{h}}$

$\eta \mathrm{h}=\frac{(1-\mathrm{t})}{(1-\mathrm{w})}$

$w=(0.5 \times C b)-0.005$

$t=k x w$

3. Delivery Horse Power (DHP) Is power distributed to propeller, with a bracket mechanical adverse and its propeller (Lewis, 1988).

$D H P=\frac{E H P}{P C}$

$$
P C=\eta H x \eta r r x \eta P
$$

4. Shaft Horse Power (SHP) Is power distributed by the actuator engine (shaft power) (Lewis, 1988).

$S H P=\frac{D H P}{\eta S \eta B}$

5. Brake Horse Power (BHP) Is used for the brake power or indicated power or power released by by the machine with the influence of the engine load (Lewis, 1988).

$$
B H P=\frac{S H P}{\eta G}
$$

The BHP above is the power released in normal sailing or SCR or $B H P_{S C R}$ which is $85 \%$ of the power released in maximum condition or MCR. The power released in the maximum condition or MCR from the main actuator engine is explained below:

$$
B H P_{M C R}=\frac{B H P}{0.85}
$$

\subsection{Propeller}

The vessel's speed can be achieved due to the power of vessel's propulsion. Currently, the most commonly used is the screw propeller. This propeller changes the engine torque into thrust power that will move the fluid around it. Propeller is generally mounted on a shaft which is located at the stern of the ship. Propeller usually works by rotating and it produces a flow velocity which is shaped like a screw, therefore it is known as Screw Propeller. The screw type of propulsor has been classified into two types: Fixed Pitch Propeller (FPP) and Controllable Pitch Propeller (CPP) (Andersen, 1994).

Screw propeller is the most common form of vessel's actuator. The number of blades in the screw propeller is ranging from three to six blades and the position is protrude from the propeller hub. The propeller's blades is the part that can be merged with a hub or can be removed and mounted on the hub like the type of propulsion system named Controllable picth Propeller. Propeller is generally placed in a low position at the rear of the ship. Propeller must have a designed diameter to accommodate the vessel to avoid air drawing phenomenon and propulsive force produced by propeller when the vessel moves in pitching state by making the propeller sufficiently in sinking condition at a full load or not-full load condition. Screw propeller is divided into two 
categories: Conventional and Unconventional Propeller (Bartee, 1975).

\subsection{Hullspeed-Maxsurf}

Hullspeed is a program to test resistance and power of the model. The test results are shown in the form of numbers and graphs. The graphs do not present only the total of resistance and power but also the coefficients of the resistance such as coefficient of total resistance $(\mathrm{CT})$, coefficient of wave resistance $(\mathrm{Cw})$, coefficient of remain resistance $(\mathrm{CR})$, coefficient of friction resistance (CF) and coefficient of viscous resistance $(\mathrm{Cv})$.

In addition to that, the program also can determine the amount of the maximum speed and magnitude of the efficiency. There are several resistance methods used for testing such as Savitsky pre-planing, Savitsky planing, Latiharju, Holtrop, van Oortmerssent, Series 60, Delft, I, II, III and Slender Body (Hamdani, 2012)

Each method can be used only for certain vessels in accordance with the type. It is because each vessels possessed different characteristics. Below is the display of Hullspeed-maxsurf software.
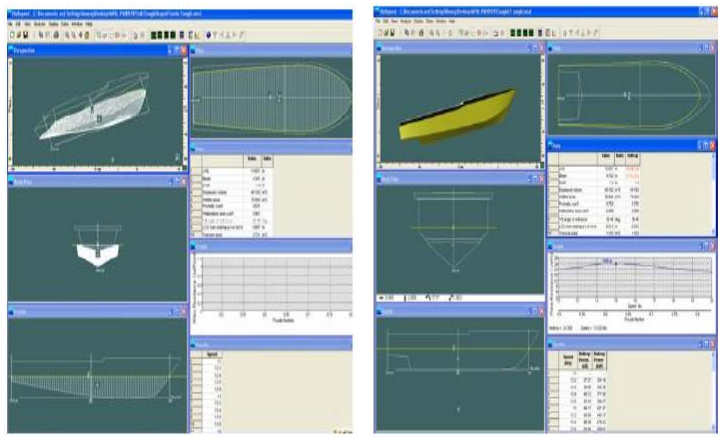

Fig.4: The Display of Hullspeed-Maxsurf (Hamdani, 2012)

\subsection{Method of Research.}

The following is the structure to be designed in this paper:

1. Analysis of vessel resistance towards the draft change of the Indonesia Navy Vessel type PC-43 with theories that support it.

2. Analysis of engine power installed towards the speed of Indonesian Navy Vessel.

Methods used in this paper were literature study, field study, model simulation and numerical calculation (Guldhammer, 1974).

\section{RESULT AND DISCUSSION}

In this part, the authors would like to discuss about resistance and power calculation of the vessel engine. Besides using formulas in the book of resistance and engine power with the help of Excel program on the computer, program named maxsurf was also used for comparison in order to maintain high accuracy in the results.

\subsection{The Resistance Calculation of The Vessel with Harvald Guldammer Method}

To calculate the total of resistance of the vessel at draught $(1.50 \mathrm{~m}$ dan $1.65 \mathrm{~m})$ in the speed of 22, 25 dan 27 knots, primary size of the vessel, lines plans, formulations, table and diagram were used. Input parameter design :
Loa
: 43 meter
Lpp
$:(\mathrm{T} 1.50=40.13$ meter $)$
( $\mathrm{T} 1.65=40.29$ meter $)$
Lwl
$:(\mathrm{T} 1.50=41.74$ meter $)$
(T $1.65=41.90$ meter)
B : 7.4 meter
$\mathrm{H} \quad: 3.4$ meter
$\mathrm{T} \quad: 1.50$ and 1.65 meter
$\mathrm{Cb} \quad: 0.496$
$\rho$ of sea water $\quad: 1.025 \mathrm{ton} / \mathrm{m}^{3}$

Table 1. The Result of Resistance Calculation of The Vessel with Harvald Guldammer Method

\begin{tabular}{|c|c|c|}
\hline $\begin{array}{c}\text { Speed } \\
\text { (Knots) }\end{array}$ & $\begin{array}{c}\text { Resistance } \\
\text { Draught T }: 1.50\end{array}$ & $\begin{array}{c}\text { Resistance } \\
\text { Draught T }: 1.65\end{array}$ \\
\hline 22 & $108.882 \mathrm{kN}$ & $126.421 \mathrm{kN}$ \\
\hline 25 & $127.307 \mathrm{kN}$ & $146.611 \mathrm{kN}$ \\
\hline 27 & $137.437 \mathrm{kN}$ & $159.478 \mathrm{kN}$ \\
\hline
\end{tabular}

\subsection{Power Calculation of The Vessel}

To calculate the total of vessel resistance at the draught of $(1.50 \mathrm{~m}$ dan $1.65 \mathrm{~m})$ in the speed of 22 , 25 and 27 knots.

Table 2. The Result of Power Calculation of The Vessel

\begin{tabular}{|c|c|c|}
\hline $\begin{array}{c}\text { Speed } \\
\text { (Knots) }\end{array}$ & $\begin{array}{c}\text { Power Draught T : } \\
1.50\end{array}$ & $\begin{array}{c}\text { Power Draught T } \\
: 1.65\end{array}$ \\
\hline 22 & $2360.24 \mathrm{HP}$ & $2741.94 \mathrm{HP}$ \\
\hline 25 & $3153.27 \mathrm{HP}$ & $3613.46 \mathrm{HP}$ \\
\hline 27 & $3658.32 \mathrm{HP}$ & $4245.04 \mathrm{HP}$ \\
\hline
\end{tabular}

\subsection{Calculation with Maxsurf}

Calculations with maxsurf is required for comparison purposes to reduce errors in the recount of the ship power requirements. It is expected that the results of the manual calculation is not too different from the result of the Maxsurf calculation. This is the result of redrawn with Maxsurf.

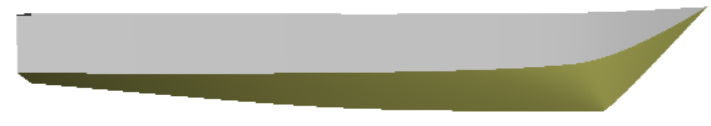

Fig.5: The Perspective Display of The Indonesian Navy Vessel

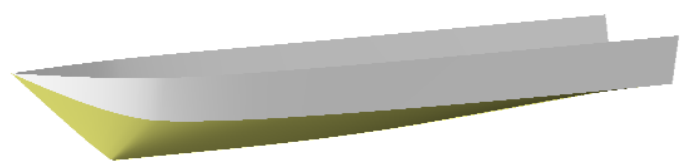

Fig.6: The Perspective Display of The Indonesian Navy Vessel 


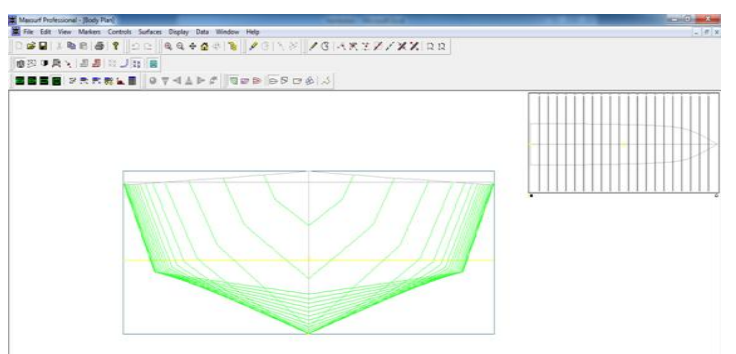

Fig.7: The Body Display Plan of the Indonesian Navy Vessel

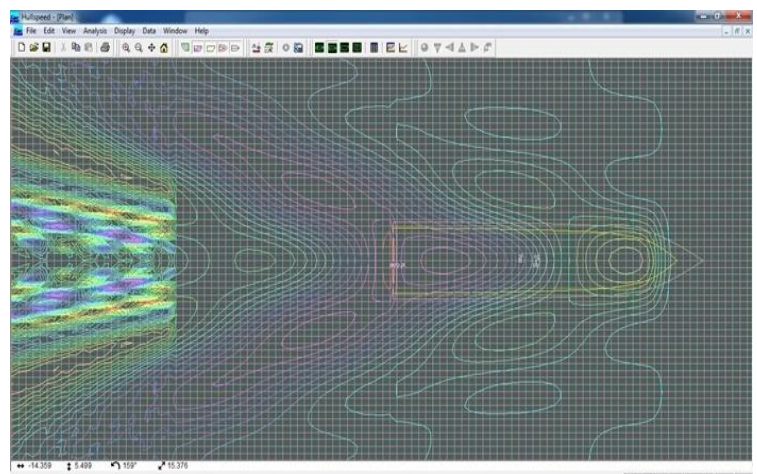

Fig.8: The Display of The Wave Surface T=1.50

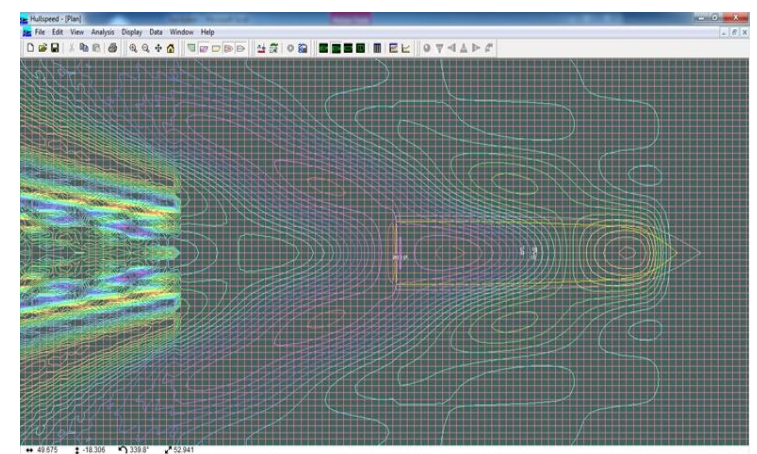

Fig.9: The Display of The Wave Surface $\mathrm{T}=1.65$

3.3.1 Result of Resistance and Power Needs Analysis at $\mathbf{T}=\mathbf{1 . 5 0}$

Here are the results of resistance and power needs analysis using Hullspeed with $72 \%$ efficiency at $\mathrm{T}=1.50$ at the maxsurf:

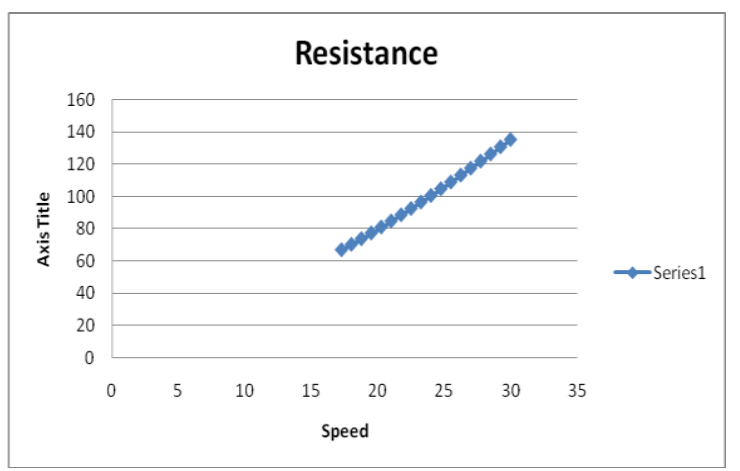

Fig.10: The Graph of Resistance $\mathrm{T}=1.50$

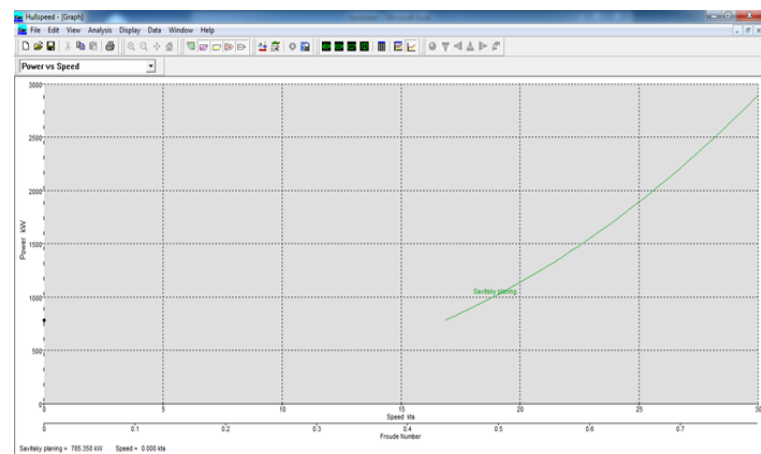

Fig.11: The Graph of Resistance vs Speed T=1.50

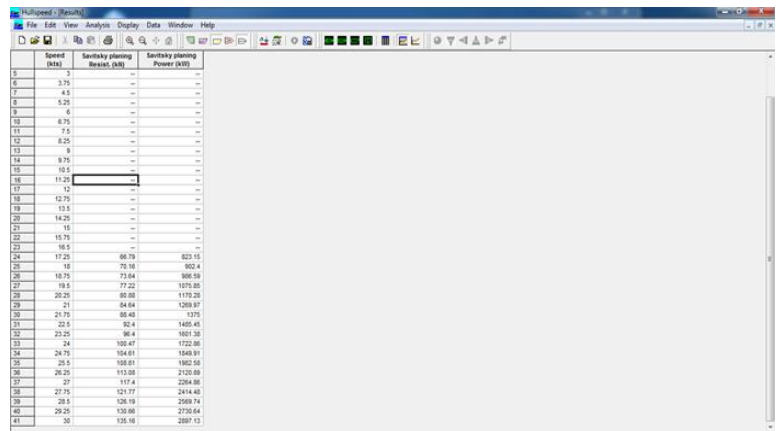

Fig.12: The Result Table of Analysis of Resistance and Power Need $\mathrm{T}=1.50$

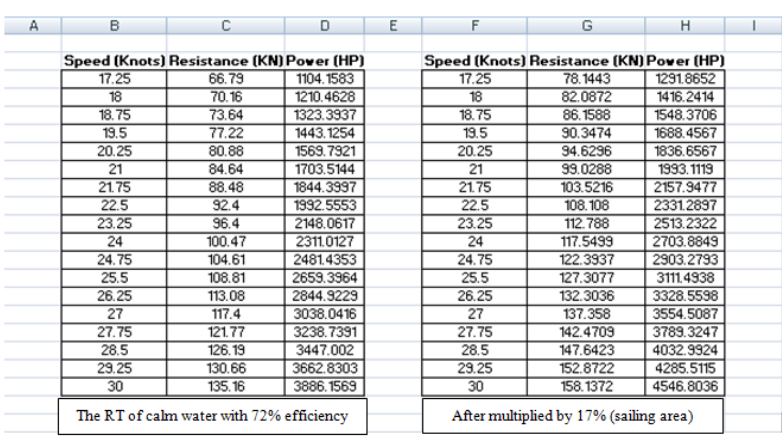

Fig.13: The Rt Table of Calm Water with $72 \%$

Efficiency, before and after timed by $17 \%$ (Sailing Area) at $\mathrm{T}=1.50$

From Fig.13: The Rt Table of calm water with $72 \%$ efficiency and after multiplied by $17 \%$ (sailing area) above with Savitsky method planning (Savitsky, 1964), it can be seen that to achieve a maximum speed of 27 knots in the draft of 1.50 meters, the power needed is $3038 \mathrm{HP}$ and resistance of 117.4 KN, which for Asia-Pacific sailing requires tolerance of $15-20 \%$, if $17 \%$ is taken then the power needed is $3554.50 \mathrm{Hp}$ and the resistance acquired is $137.358 \mathrm{KN}$.

\subsubsection{Result of Resistance and Power Needs Analysis at $\mathbf{T}=\mathbf{1 . 6 5}$}

Here are the results of resistance and power needs analysis using Hullspeed with $72 \%$ efficiency at $\mathrm{T}=1.65$ at the maxsurf: 


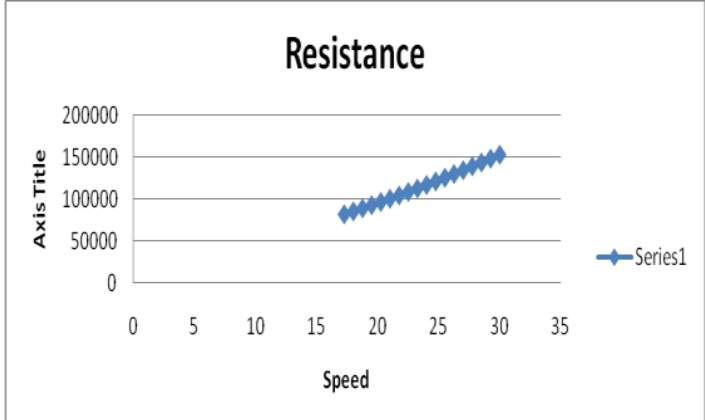

Fig. 14: The Graph of Resistance $\mathrm{T}=1.65$

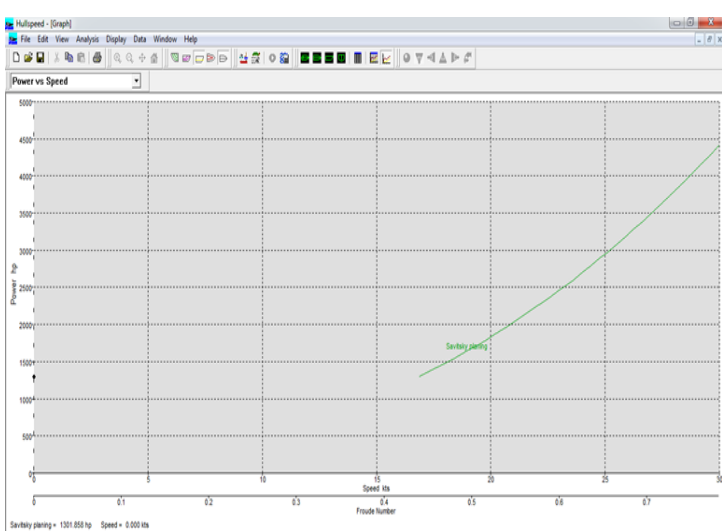

Fig.15: The Graph of Resistance vs Speed $\mathrm{T}=1.65$

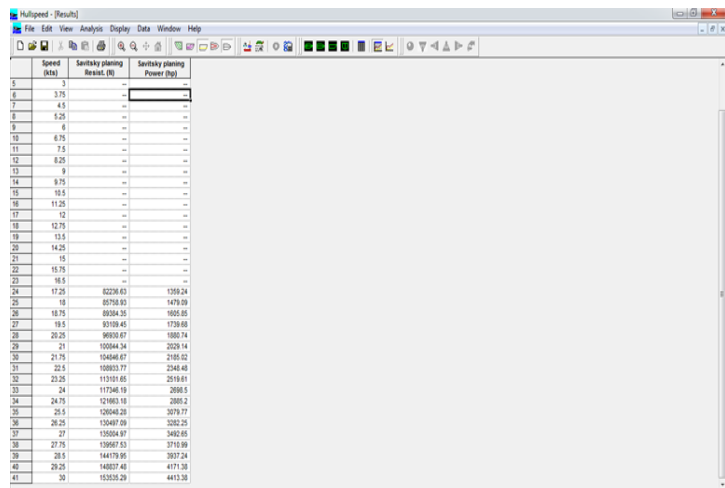

Fig.16: The Result Table of Analysis of Resistance and Power Need $\mathrm{T}=1.65$

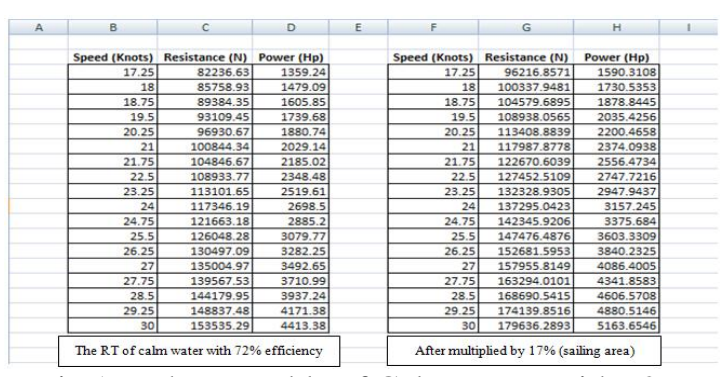

Fig.17: The Rt Table of Calm Water with $72 \%$

Efficiency, before and after timed by 17\% (Sailing Area) at $\mathrm{T}=1.65$

From Fig.17: The Rt Table of calm water with $72 \%$ efficiency and after multiplied by $17 \%$ (sailing area) above with Savitsky method planning (Savitsky, 1964), it can be seen that to achieve a maximum speed of 27 knots in the draft of 1.65 meters, the power needed is $3492.65 \mathrm{HP}$ and resistance of $135 \mathrm{KN}$, which for Asia-Pacific sailing requires tolerance of $15-20 \%$, if $17 \%$ is taken then the power needed is $4086.40 \mathrm{Hp}$ and the resistance acquired is $157.955 \mathrm{KN}$.

\subsection{Discussion}

The comparison between the manual and maxsurf calculation towards the Resistance and Power at draught of $\mathrm{T}=1.50$ and $\mathrm{T}=1.65$ with speed of 22,25 , 27 knot.

Table 3. Comparison Between Manual and Maxsurf Resistance in Draught $\mathrm{T}=1.50$

\begin{tabular}{|c|c|c|}
\hline $\begin{array}{c}\text { Speed } \\
\text { (knots) }\end{array}$ & $\begin{array}{c}\text { Resistance } \\
\text { (manual) }\end{array}$ & $\begin{array}{c}\text { Resistance } \\
\text { (maxsurf) }\end{array}$ \\
\hline 22 & $108.882 \mathrm{kN}$ & $108.108 \mathrm{kN}$ \\
\hline 25 & $127.307 \mathrm{kN}$ & $127.307 \mathrm{kN}$ \\
\hline 27 & $137.437 \mathrm{kN}$ & $137.354 \mathrm{kN}$ \\
\hline
\end{tabular}

Table 4. Comparison Between Manual and Maxsurf Resistance in Draught $\mathrm{T}=1.65$

\begin{tabular}{|c|c|c|}
\hline $\begin{array}{c}\text { Speed } \\
\text { (knots) }\end{array}$ & $\begin{array}{c}\text { Resistance } \\
\text { (manual) }\end{array}$ & $\begin{array}{c}\text { Resistance } \\
\text { (maxsurf) }\end{array}$ \\
\hline 22 & $126.421 \mathrm{kN}$ & $127.45 \mathrm{kN}$ \\
\hline 25 & $146.611 \mathrm{kN}$ & $147.47 \mathrm{kN}$ \\
\hline 27 & $157.478 \mathrm{kN}$ & $157.95 \mathrm{kN}$ \\
\hline
\end{tabular}

Table 5. Comparison Between Manual and Maxsurf Power (BHPscr) in Draught T $=1.50$

\begin{tabular}{|c|c|c|}
\hline $\begin{array}{c}\text { Speed } \\
\text { (knots) }\end{array}$ & $\begin{array}{c}\text { Power (manual) } \\
\text { BHPscr }\end{array}$ & $\begin{array}{c}\text { Power (maxsurf) } \\
\text { BHPscr }\end{array}$ \\
\hline $\mathrm{V}=22$ & $2360.24 \mathrm{HP}(\mathrm{V}=$ & $\begin{array}{c}2331.28 \mathrm{HP}(\mathrm{V}= \\
22.5)\end{array}$ \\
\hline $\mathrm{V}=25$ & $3153.27 \mathrm{HP}(\mathrm{V}=$ & $\begin{array}{c}3111.49 \mathrm{HP}(\mathrm{V}= \\
25)\end{array}$ \\
\hline $\mathrm{V}=27$ & $3658.32 \mathrm{HP}(\mathrm{V}=$ & $\begin{array}{c}3554.50 \mathrm{HP}(\mathrm{V}= \\
\end{array}$ \\
$27)$ & $27)$ \\
\hline
\end{tabular}

Table 6. Comparison Between Manual and Maxsurf Power (BHPscr) in Draught T=1.65

\begin{tabular}{|c|c|c|}
\hline $\begin{array}{c}\text { Speed } \\
\text { (knots) }\end{array}$ & $\begin{array}{c}\text { Power (manual) } \\
\text { BHPscr }\end{array}$ & $\begin{array}{c}\text { Power (maxsurf) } \\
\text { BHPscr }\end{array}$ \\
\hline $\mathrm{V}=22$ & $\begin{array}{c}2741.94 \mathrm{HP}(\mathrm{V}= \\
22)\end{array}$ & $\begin{array}{c}2747.72 \mathrm{HP}(\mathrm{V}= \\
22.5)\end{array}$ \\
\hline $\mathrm{V}=25$ & $\begin{array}{c}3613.46 \mathrm{HP}(\mathrm{V}= \\
25)\end{array}$ & $\begin{array}{c}3603.33 \mathrm{HP}(\mathrm{V}= \\
25.5)\end{array}$ \\
\hline $\mathrm{V}=27$ & $\begin{array}{c}4245.04 \mathrm{HP}(\mathrm{V}= \\
\end{array}$ & $\begin{array}{c}4086.40 \mathrm{HP}(\mathrm{V}= \\
27)\end{array}$ \\
\hline
\end{tabular}

\section{CONCLUSION}

From the calculation of the draught of $\mathrm{T}=1.65$ meters and $\mathrm{V}=27$ knots, maximum power is obtained by BHPscr $=4245.04 \mathrm{HP}$, while the total power 
engines installed in the vessel $(3 \times 1800 \mathrm{HP})=5400$ HP (BHP). Thus the expected of the vessel speed (27 knots) can be achieved, so that the vessel can be operated as its basic function of "LIMITED PATROL CRAFT" with the adjustment of the speed and the condition of the waters where the vessel is operated.

\section{ACKNOWLEDGEMENTS}

This research has been Supported by Indonesia Naval Technology College (STTAL).

\section{REFERENCES}

[1]. Andersen, J. P. (1994). Hydrodynamic of Ship Propellers. Cambridge: Cambridge University Press.

[2]. Anthony F. Molland, S. R. (2011). Ship Resistance and Propulsion : Practical Estimation of Ship Propulsive Power. United Stated of America: Cambridge University Press.

[3]. Bartee, D. L. (1975). Design of Propulsion Systems for High-Speed Craft. The Society of Naval Architects and Marine Engineers. , 1-17.

[4]. Bertram, H. S. (1998). Ship Design for Efficiency and Economy. Great Britain: Butterworth-Heinemann.

[5]. Bertram, V. (2000). Practical Ship Hydrodynamic. Great Britain: ButterworthHeinemann.

[6]. Charchalis, A. (2013). Designing Constraints in Evaluation of Ship Propulsion Power. Journal of KONES Powertrain and Transport , 1-6.

[7]. D'arcalengelo, A. M. (1969). Ship Design and Contruction. Michigan: Professor of Naval Architecture and Marine Engineering University of Machigan.

[8]. Guldhammer, H. E. (1974). Ship Resistance. Copenhagen: Akademisk Forlag.

[9]. Hamdani, I. U. (2012). Kajian Interferensi Koefisien Hambatan pada Lambung Katamaran melalui Komputasi 'Slender Body Method. Directory of open access journals , 1-10.

[10]. Harvald, S. A. (1992). Resistance and Propulsion of Ships. New York: John Wiley and Sons.

[11]. Holtrop, J. a. (1982). An Approximate Power Prediction Method. english: International Shipbuilding Progress.

[12]. J. Sladky, J. (1976). Marine Propulsion. New York: The Winter Annual Meeting of The American Society of Marine Engineers.

[13]. Kleppesto, K. (2015). Empirical Prediction of Resistance of Fishing Vessels. NTNU Trondheim Norwegian University of Science And Technology , 1-87.

[14]. Kuiper, G. (1992). The Wageningen Propeller Series. Netherland: MARIN.
[15]. Lewis, E. V. (1988). Principles of Naval Architecture Second Revision. New Jersey: The Society of Naval Architecs and Marine Engineers.

[16]. Premchand, P. K. (2015). Numerical Investigation of the Influence of Water Depth on Ship Resistance. International Journal of Computer Applications , 1-8.

[17]. Samuel, M. I. (2015). An Inventigation Into The Resistance Components of Converting a Traditional Monohull Fishing Vessel Into Catamaran Form. International Journal of Technology , 1-10.

[18]. Savitsky, D. (1964). Hydrodynamic Design of Planing Hulls. Paris: Marine Technology.

[19]. Tabaczek, J. K. (2014). Coefficients of Propeller-hull Interaction in Propulsion System of Inland Waterway Vessels with Stern Tunnels. International Journal on Marine Navigation and Safety of Sea Transportation , 1-8.

[20]. Tupper, E. (1975). Introduction to Naval Architecture. Great Britain: Naval Architecture for Marine Engineers.

[21]. Tupper, K. R. (2001). Basic Ship Theory. Great Britain: Longman Group Limited.

[22]. Watson, D. G. (1998). Practical Ship Design. Netherlands: Elsevier Science Ltd.

[23]. Wehausen, J. V. (1971). The Wave Resistance of Ships. California: Depart. of Naval Architecture.

[24]. WPA Van Lamerren, T. L. (1948). Resistance Propulsion and Steering of Ship. Holland: Harlem.

[25]. Zelazny, K. (2014). Amethod of Calculation of Ship Resistance on Calm Water Useful at Preliminary Stages of Ship Design. Scientific Journal Maritime University of Szuczecin , 125-130. 